\title{
Interleukin-6 Receptor Antagonists in Critically III Patients with Covid-19 - Preliminary report
}

\author{
The REMAP-CAP Investigators
}

\section{Author and Group Information}

The members of the writing committee appear below and the full list of investigators and collaborators appear in the Supplementary Appendix.

\section{Writing Committee:}

Anthony C. Gordon, MBBS, MD ${ }^{1,2}$; Paul R. Mouncey, MSc ${ }^{3}$; Farah Al-Beidh, PhD ${ }^{1}$; Kathryn M. Rowan, PhD ${ }^{3}$; Alistair D. Nichol, MD, PhD ${ }^{4,5,6}$; Yaseen M. Arabi, MD ${ }^{7}$; Djillali Annane, MD, PhD 8,9,10; Abi Beane, PhD ${ }^{11}$; Wilma van Bentum-Puijk, MSc ${ }^{12}$; Lindsay R. Berry, PhD ${ }^{13}$; Zahra Bhimani, MPH ${ }^{14}$; Marc J.M. Bonten, MD, PhD ${ }^{12}$; Charlotte A. Bradbury, MBChB, PhD ${ }^{15}$; Frank M. Brunkhorst, MD, PhD ${ }^{16}$; Adrian Buzgau, MSc ${ }^{4}$; Allen C. Cheng, MD, PhD ${ }^{4,17}$; Michelle A. Detry, PhD ${ }^{13}$; Eamon J. Duffy, BPharm ${ }^{18}$; Lise J. Estcourt, MBBCh, PhD ${ }^{19}$; Mark Fitzgerald, PhD ${ }^{13}$; Herman Goossens, PhD ${ }^{20}$; Rashan Haniffa, PhD 21,22,23; Alisa M. Higgins, PhD ${ }^{4}$; Thomas E. Hills, PhD ${ }^{24,25}$; Christopher M. Horvat, $\mathrm{MD}^{26}$; Francois Lamontagne, MD ${ }^{27}$; Patrick R. Lawler, MD, MPH ${ }^{28,29}$; Helen L. Leavis, MD, PhD ${ }^{12}$; Kelsey M. Linstrum, MS ${ }^{30}$; Edward Litton, MD, PhD ${ }^{31,32}$; Elizabeth Lorenzi, $\mathrm{PhD}^{13}$; John C. Marshall, MD ${ }^{14}$; Florian B. Mayr, MD, MPH ${ }^{30}$; Danny McAuley, MD ${ }^{33,34}$; Anna McGlothlin, PhD ${ }^{13}$; Shay P McGuinness, MD ${ }^{4,24,25}$; Bryan J. McVerry, MD ${ }^{30}$; Stephanie K. Montgomery, MSc ${ }^{30}$; Susan C. Morpeth, MD, PhD ${ }^{35}$; Srinivas Murthy, MD ${ }^{36}$; Katrina Orr, BPharm ${ }^{37}$; Rachael L. Parke, PhD ${ }^{24,38}$; Jane C. Parker, BN ${ }^{4}$; Asad E. Patanwala, PharmD, MPH ${ }^{39,40}$; Ville Pettilä, MD ${ }^{41}$; Emma Rademaker, MD, MSc ${ }^{12}$; Marlene S. Santos, MD, MSHS ${ }^{14}$; Christina T. Saunders, $\mathrm{PhD}^{13}$; Christopher W. Seymour, MD, MSc ${ }^{30}$; Manu Shankar-Hari, MD, PhD ${ }^{42,43}$; Wendy I. Sligl, MD, MSc ${ }^{44}$; Alexis F. Turgeon, MD, $\mathrm{MSc}^{45}$; Anne M. Turner, MPH ${ }^{25}$; Frank L. van de Veerdonk, MD, PhD ${ }^{46}$; Ryan Zarychanski, MD, MSc 47; Cameron Green, MSc ${ }^{4}$; Roger J. Lewis, MD, PhD ${ }^{13,48}$; Derek C. Angus, MD, MPH ${ }^{30}$; Colin J. McArthur, MD ${ }^{24}$; Scott Berry, PhD ${ }^{13}$; Steve A. Webb, MD, PhD ${ }^{4,49}$; Lennie P.G. Derde, MD, PhD ${ }^{12}$.

1. Imperial College London, London, United Kingdom

2. Imperial College Healthcare NHS Trust, St. Mary's Hospital, London, United Kingdom

3. Intensive Care National Audit \& Research Centre (ICNARC), London, United Kingdom

4. Monash University, Melbourne, Australia

5. University College Dublin, Dublin, Ireland

6. Alfred Health, Melbourne, Australia

7. King Saud bin Abdulaziz University for Health Sciences and King Abdullah International Medical Research Center, Riyadh, Kingdom of Saudi Arabia

8. Hospital Raymond Poincaré (Assistance Publique Hôpitaux de Paris), Garches, France

9. Université Versailles SQY - Université Paris Saclay, Montigny-le-Bretonneux, France

10. Université Paris Saclay - UVSQ - INSERM, Garches, France

11. University of Oxford, Oxford, United Kingdom

12. University Medical Center Utrecht, Utrecht, The Netherlands

13. Berry Consultants, Austin, United States

14. St. Michael's Hospital Unity Health, Toronto, Canada

15. University of Bristol, Bristol, United Kingdom

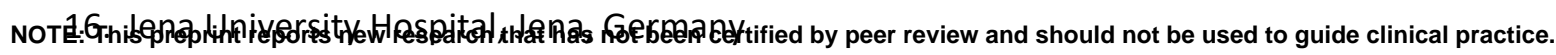


medRxiv preprint doi: https://doi.org/10.1101/2021.01.07.21249390; this version posted January $9,2021$. The copyright holder for this preprint (which was not certified by peer review) is the author/funder, who has granted medRxiv a license to display the preprint in It is made available under a CC-BY-NC-ND 4.0 International license.

17. Alfred Health, Melbourne, Australia

18. Auckland District Health Board, Auckland, New Zealand

19. NHS Blood and Transplant, Oxford, United Kingdom

20. University of Antwerp, Wilrijk, Belgium

21. University of Oxford, Bangkok, Thailand

22. University College London Hospital, London, United Kingdom

23. National Intensive Care Surveillance (NICST), Colombo, Sri Lanka

24. Auckland City Hospital, Auckland, New Zealand

25. Medical Research Institute of New Zealand (MRINZ), Wellington, New Zealand

26. UPMC Children's Hospital of Pittsburgh, Pittsburgh, United States

27. Université de Sherbrooke, Sherbrooke, Quebec, Canada

28. University Health Network, Toronto, Canada

29. University of Toronto, Toronto, Canada

30. University of Pittsburgh, Pittsburgh, United States

31. Fiona Stanley Hospital, Perth, Australia

32. University of Western Australia, Perth, Australia

33. Queen's University Belfast, Belfast, Northern Ireland

34. Royal Victoria Hospital, Belfast, Northern Ireland

35. Middlemore Hospital, Auckland, New Zealand

36. University of British Columbia, Vancouver, Canada

37. Fiona Stanley Hospital, Perth, Australia

38. University of Auckland, Auckland, New Zealand

39. University of Sydney, Sydney, Australia

40. Royal Prince Alfred Hospital, Sydney, Australia

41. University of Helsinki and Helsinki University Hospital, Helsinki, Finland

42. King's College London, London, United Kingdom

43. Guy's and St Thomas' NHS Foundation Trust, London, United Kingdom

44. University of Alberta, Edmonton, Canada

45. Université Laval, Québec City, Canada

46. Radboudumc, Nijmegen, The Netherlands

47. University of Manitoba, Winnipeg, Canada

48. Harbor-UCLA Medical Center, Torrance, CA, United States

49. St John of God Hospital, Subiaco, Australia

\title{
Keywords
}

Adaptive platform trial; intensive care; pneumonia; pandemic; Covid-19; tocilizumab; sarilumab; interleukin-6

\section{Corresponding Author}

\author{
Anthony C Gordon, MB BS, MD \\ Division of Anaesthetics, Pain Medicine \& Intensive Care \\ Imperial College London, St Mary's Hospital \\ Praed Street \\ London, W2 1NY, UK
}

Email: anthony.gordon@imperial.ac.uk 
medRxiv preprint doi: https://doi.org/10.1101/2021.01.07.21249390; this version posted January 9, 2021. The copyright holder for this preprint (which was not certified by peer review) is the author/funder, who has granted medRxiv a license to display the preprint in It is made available under a CC-BY-NC-ND 4.0 International license .

\section{Abstract}

\section{Background}

The efficacy of interleukin- 6 receptor antagonists in critically ill patients with coronavirus disease 2019 (Covid-19) is unclear.

\section{Methods}

We evaluated tocilizumab and sarilumab in an ongoing international, multifactorial, adaptive platform trial. Adult patients with Covid-19, within 24 hours of commencing organ support in an intensive care unit, were randomized to receive either tocilizumab $(8 \mathrm{mg} / \mathrm{kg})$ or sarilumab (400mg) or standard care (control). The primary outcome was an ordinal scale combining in-hospital mortality (assigned -1) and days free of organ support to day 21 . The trial uses a Bayesian statistical model with pre-defined triggers to declare superiority, efficacy, equivalence or futility.

\section{Results}

Tocilizumab and sarilumab both met the pre-defined triggers for efficacy. At the time of full analysis 353 patients had been assigned to tocilizumab, 48 to sarilumab and 402 to control. Median organ support-free days were 10 (interquartile range [IQR] -1, 16), 11 (IQR 0, 16) and $0($ IQR $-1,15)$ for tocilizumab, sarilumab and control, respectively. Relative to control, median adjusted odds ratios were 1.64 (95\% credible intervals [Crl] 1.25, 2.14) for tocilizumab and $1.76(95 \% \mathrm{Crl} 1.17,2.91)$ for sarilumab, yielding $>99.9 \%$ and $99.5 \%$ posterior probabilities of superiority compared with control. Hospital mortality was $28.0 \%(98 / 350)$ for tocilizumab, $22.2 \%$ (10/45) for sarilumab and 35.8\% (142/397) for control. All secondary outcomes and analyses supported efficacy of these IL-6 receptor antagonists. 
medRxiv preprint doi: https://doi.org/10.1101/2021.01.07.21249390; this version posted January 9, 2021. The copyright holder for this preprint (which was not certified by peer review) is the author/funder, who has granted medRxiv a license to display the preprint in It is made available under a CC-BY-NC-ND 4.0 International license .

\section{Conclusions}

In critically ill patients with Covid-19 receiving organ support in intensive care, treatment with the IL-6 receptor antagonists, tocilizumab and sarilumab, improved outcome, including survival. (ClinicalTrials.gov number: NCT02735707) 
medRxiv preprint doi: https://doi.org/10.1101/2021.01.07.21249390; this version posted January 9, 2021. The copyright holder for this preprint (which was not certified by peer review) is the author/funder, who has granted medRxiv a license to display the preprint in It is made available under a CC-BY-NC-ND 4.0 International license.

\section{Background}

Globally, there have been over 79 million reported cases of Coronavirus Infectious Disease 2019 (Covid-19) with over 1.75 million deaths. ${ }^{1}$ Only corticosteroids are known to improve survival for severely ill patients. ${ }^{2}$ The benefit from corticosteroids in critically ill patients supports the concept that an excessive host inflammatory response is responsible for much of the morbidity and mortality from Covid-19.

Interleukin-6 (IL-6) is released in response to infection and stimulates inflammatory pathways as part of the acute phase response. Tocilizumab and sarilumab are monoclonal antibodies that inhibit both membrane-bound and soluble IL-6 receptors and are used to treat inflammatory conditions, such as rheumatoid arthritis, and cytokine release syndrome after chimeric antigen receptor T-cell (CAR-T) therapy (tocilizumab). Their clinical use has been described in Covid-19, ${ }^{3-5}$ however, randomized controlled trials to date have been inconclusive. ${ }^{6-10}$

We investigated the effectiveness of tocilizumab and sarilumab on survival and organ support in critically ill patients with Covid-19 in the Randomized, Embedded, Multifactorial Adaptive Platform Trial for Community-Acquired Pneumonia (REMAP-CAP). 
medRxiv preprint doi: https://doi.org/10.1101/2021.01.07.21249390; this version posted January $9,2021$. The copyright holder for this preprint (which was not certified by peer review) is the author/funder, who has granted medRxiv a license to display the preprint in It is made available under a CC-BY-NC-ND 4.0 International license .

\section{Methods}

\section{Trial Design and Oversight}

REMAP-CAP is an international, adaptive platform trial designed to determine best treatment strategies for patients with severe pneumonia in both pandemic and nonpandemic settings. REMAP-CAP's design and first results, regarding corticosteroids in Covid19, were published previously. ${ }^{11,12}$

Patients eligible for the platform are assessed for eligibility and potentially randomized to multiple interventions across multiple domains. A 'domain' covers a common therapeutic area (e.g., antiviral therapy) and contains two or more interventions (including control e.g. 'no antiviral'). Patients are randomized to one intervention in each domain for which they are eligible. The REMAP-CAP trial is defined by a master ('core') protocol with individual appendices for each domain, regional governance and adaptations for a declared pandemic. The trial is overseen by a blinded International Trial Steering Committee (ITSC) and an unblinded independent Data and Safety Monitoring Board (DSMB). The trial is approved by relevant regional ethics committees (see Supplementary Appendix for more detail) and is conducted in accordance with Good Clinical Practice guidelines and the principles of the Declaration of Helsinki. Written or verbal informed consent, in accordance with regional legislation, is obtained from all patients or their surrogates.

The trial has multiple funders, internationally, with multiple regional sponsors. Roche Products Ltd and Sanofi supported the trial through provision of tocilizumab and sarilumab in the United Kingdom. The funders, sponsors, and Roche and Sanofi had no role in designing the trial, analyzing data, writing the manuscript, or making the decision to submit for publication. All authors vouch for the data and analyses, as well as for the fidelity of this report to the trial protocol and statistical analysis plan. 
medRxiv preprint doi: https://doi.org/10.1101/2021.01.07.21249390; this version posted January 9, 2021. The copyright holder for this

preprint (which was not certified by peer review) is the author/funder, who has granted medRxiv a license to display the preprint in It is made available under a CC-BY-NC-ND 4.0 International license .

\section{Participants}

Critically ill patients, aged $\geq 18$ years, with suspected or confirmed Covid-19, admitted to an intensive care unit (ICU) and receiving respiratory or cardiovascular organ support were classified as severe state and were eligible for enrollment in the Covid-19 Immune Modulation Therapy domain. Exclusion criteria included presumption that death was imminent with lack of commitment to full support, and prior participation in REMAP-CAP within 90 days. Additional exclusion criteria, specific for the Immune Modulation Therapy domain, are listed in the Supplementary Appendix.

\section{Randomization}

The Immune Modulation Therapy domain included five interventions: two IL-6 receptor antagonists, tocilizumab and sarilumab; an IL-1 receptor antagonist, anakinra; and interferon beta-1a; as well as control (no immune modulation). Investigators at each site selected a priori at least two interventions, one of which had to be control, to which patients would be randomized. Participants were randomized via centralized computer program to each intervention (available at the site) starting with balanced assignment for tocilizumab, sarilumab or control (e.g. 1:1 if two interventions available, 1:1:1 if three interventions available).

Tocilizumab, at a dose of $8 \mathrm{mg} / \mathrm{kg}$ of actual body weight (up to a maximum of $800 \mathrm{mg}$ ), was administered as an intravenous infusion over one hour; this dose could be repeated 12-24 hours later at the discretion of the treating clinician. Sarilumab, 400mg, was administered as an intravenous infusion once only. All investigational drugs were dispensed by local pharmacies and were open-label. 
medRxiv preprint doi: https://doi.org/10.1101/2021.01.07.21249390; this version posted January 9, 2021. The copyright holder for this preprint (which was not certified by peer review) is the author/funder, who has granted medRxiv a license to display the preprint in It is made available under a CC-BY-NC-ND 4.0 International license .

\section{Procedures}

Other aspects of patient management were provided per each site's standard of care. In addition to assignments in this domain, participants could be randomized to other interventions within other domains, depending on domains active at the site, patient eligibility, and consent (see www.remapcap.org). Randomization to the Corticosteroid domain for Covid-19 closed on June 17, 2020.12 Thereafter, corticosteroids were allowed as per recommended standard of care.

Although clinical staff were aware of individual patient intervention assignment, neither they nor the ITSC were provided any information about aggregate patient outcomes.

\section{Outcome Measures}

The primary outcome was respiratory and cardiovascular organ support-free days up to day 21. In this composite ordinal outcome, all deaths within hospital are assigned the worst outcome (-1). Among survivors, respiratory and cardiovascular organ support-free days are calculated up to day 21 , such that a higher number represents faster recovery. This outcome was used in a recent Food and Drug Administration approved trial and 1.5 days was considered a minimally clinically important difference. ${ }^{13}$ Secondary outcomes were all prespecified and details are in the Supplementary Appendix.

\section{Statistical Analysis}

REMAP-CAP uses a Bayesian design with no maximum sample size. Regular, interim analyses are conducted and randomization continues, potentially with response-adaptive randomization with preferential assignment to those interventions that appear most favorable, until a pre-defined statistical trigger is met. 
medRxiv preprint doi: https://doi.org/10.1101/2021.01.07.21249390; this version posted January 9, 2021. The copyright holder for this preprint (which was not certified by peer review) is the author/funder, who has granted medRxiv a license to display the preprint in It is made available under a CC-BY-NC-ND 4.0 International license .

The primary analysis was generated from a Bayesian cumulative logistic model, which calculated posterior probability distributions of the 21-day organ support-free days (primary outcome) based on evidence accumulated in the trial and assumed prior knowledge in the form of a prior distribution. Prior distributions for individual treatment effects were neutral. The primary model adjusted for location (site, nested within country), age (categorized into six groups), sex, and time-period (two-week epochs). The model contained treatment effects for each intervention within each domain and pre-specified treatment-by-treatment interactions across domains. The treatment effects for tocilizumab and sarilumab were "nested" in the model with a hierarchical prior distribution sharing a common mean and variance. This prior structure facilitates dynamic borrowing between the two IL-6 receptor antagonists that borrows more information when the observed effects are similar and less when they are different. ${ }^{14}$

The primary analysis was conducted on all severe state patients with Covid-19 randomized to any domain up to November 19, 2020 (and with complete follow-up). The inclusion of additional patients enrolled outside the Immune Modulation Therapy domain allows maximal incorporation of all information, providing the most robust estimation of the coefficients of all covariates, as per the principle of the REMAP-CAP design. ${ }^{11,12}$ Importantly, not all patients were eligible for all domains nor for all interventions (dependent on active domains and interventions at the site, eligibility criteria, and patient/surrogate consent). Therefore, the model included covariate terms reflecting each patient's domain eligibility, such that the estimate of an intervention's effectiveness, relative to any other intervention within that domain, was generated from those patients that might have been eligible to be randomized to those interventions within the domain. 
medRxiv preprint doi: https://doi.org/10.1101/2021.01.07.21249390; this version posted January $9,2021$. The copyright holder for this preprint (which was not certified by peer review) is the author/funder, who has granted medRxiv a license to display the preprint in It is made available under a CC-BY-NC-ND 4.0 International license .

The cumulative log odds for the primary outcome was modeled such that a parameter $>0$ reflects an increase in the cumulative log odds for the organ support-free days outcome, implying benefit. There was no imputation of missing outcomes. The model was fit using a Markov Chain Monte Carlo algorithm that drew iteratively (10,000 draws) from the joint posterior distribution, allowing calculation of odds ratios with their $95 \%$ credible intervals (Crl) and the probability that each intervention (including control) was optimal in the domain, that an intervention was superior compared with control (efficacy), that two noncontrol interventions were equivalent, or an intervention was futile compared with control. An odds ratio $>1$ represents improved survival and/or more organ support-free days. The pre-defined statistical triggers for trial conclusions and disclosure of results were: a $>99 \%$ posterior probability that an intervention was optimal compared with all other interventions; an inferiority conclusion if $<0.25 \%$ posterior probability that an intervention was optimal; an intervention efficacy if $>99 \%$ posterior probability the odds ratio was $>1$ compared with control; intervention futility if $<5 \%$ posterior probability the odds ratio was $>1.2$ compared with control, or equivalence if $>90 \%$ probability the odds ratio was between $1 / 1.2$ and 1.2 for two non-control interventions.

Analysis of the primary outcome was then repeated in a second model using only data from those patients enrolled in domains that had stopped and were unblinded at the time of analysis with no adjustment for assignment in other ongoing domains. The secondary outcomes were also analyzed in this second model. One subgroup analysis, based on terciles of serum C-reactive protein (CRP) at inclusion, was pre-specified. Further details of all analyses are provided in the Supplementary Appendix. Pre-specified analyses are listed in the statistical analysis plan. Data management and summaries were created using $R$ version 
medRxiv preprint doi: https://doi.org/10.1101/2021.01.07.21249390; this version posted January 9, 2021. The copyright holder for this preprint (which was not certified by peer review) is the author/funder, who has granted medRxiv a license to display the preprint in It is made available under a CC-BY-NC-ND 4.0 International license .

3.6.0, the primary analysis was computed in $\mathrm{R}$ version 4.0.0 using the rstan package version 2.21.1. Additional data management and analyses were performed in SQL 2016, SPSS version 26, and Stata version 14.2. 
medRxiv preprint doi: https://doi.org/10.1101/2021.01.07.21249390; this version posted January $9,2021$. The copyright holder for this preprint (which was not certified by peer review) is the author/funder, who has granted medRxiv a license to display the preprint in It is made available under a CC-BY-NC-ND 4.0 International license .

\section{Results}

These are preliminary results. As further follow-up and analysis continues, minor changes may occur.

The first patient with Covid-19 was enrolled into REMAP-CAP on March 9, 2020 and the first patient randomized in the Immune Modulation Therapy domain on April 19 as tocilizumab became available. Sarilumab only became available later. At a scheduled interim analysis, the independent DSMB reported that tocilizumab had met the statistical trigger for efficacy (posterior probability $99.75 \%$, odds ratio $1.87,95 \% \mathrm{Crl} 1.20,2.76$ ) based on an interim analysis of patients as of October 28. As per protocol, further assignment to control closed on November 19 with randomization continuing between different active immune modulation interventions. At this time, 2,046 patients had been randomized in at least one domain in the severe disease state of REMAP-CAP and 895 had been randomized in the Immune Modulation Therapy domain (366 to tocilizumab, 48 to sarilumab, 412 to control and 69 to other interventions within the domain) in 113 sites across six countries (Figure 1). Thirty patients subsequently withdrew consent, and 11 patients had missing primary outcome data. Following a subsequent interim analysis, the DSMB reported that sarilumab had also met the statistical trigger for efficacy and so these results are also reported.

\section{Patients}

Baseline characteristics were balanced across intervention groups and typical of a critically ill population with Covid-19 (Table 1). All but three patients were receiving respiratory support at the time of randomization, including high flow nasal oxygen (28.8\%), noninvasive (41.5\%) and invasive (29.4\%) mechanical ventilation. The majority of patients $(n=707)$ were enrolled after June 17 and the announcement of the dexamethasone result 
medRxiv preprint doi: https://doi.org/10.1101/2021.01.07.21249390; this version posted January 9, 2021. The copyright holder for this preprint (which was not certified by peer review) is the author/funder, who has granted medRxiv a license to display the preprint in It is made available under a CC-BY-NC-ND 4.0 International license .

from the RECOVERY trial ${ }^{15}$ and of these patients, 93.3\% (610/654) were treated with corticosteroids at enrollment or within the following 48 hours. Of the 158 patients recruited before June 17, 107 were randomized in the previously published Corticosteroid domain within REMAP-CAP, 41 allocated to a seven-day course of hydrocortisone and 39 to shockdependent hydrocortisone. ${ }^{12}$ Remdesivir use was recorded in $32.8 \%$ (265/807) of patients.

In the tocilizumab group, $92 \%$ received at least one dose, $29 \%$ receiving a second dose at the discretion of the treating clinician. In the sarilumab group, $90 \%$ received the allocated drug and in the control group, $2 \%$ were given one of the immune modulating drugs outside the trial protocol.

\section{Primary Outcome}

Median organ support-free days were 10 (interquartile range [IQR] -1, 16), 11 (IQR 0, 16) and $0($ IQR $-1,15)$ for tocilizumab, sarilumab and control groups, respectively (Table 2 and Figure 2). Compared with control, median adjusted odds ratios (primary model) were 1.64 $(95 \% \mathrm{Crl} 1.25,2.14)$ for tocilizumab and $1.76(95 \% \mathrm{Crl} 1.17,2.91)$ for sarilumab, yielding $>99.9 \%$ and $99.5 \%$ posterior probabilities of superiority. Hospital mortality was $28.0 \%$ (98/350) for tocilizumab, $22.2 \%(10 / 45)$ for sarilumab and $35.8 \%(142 / 397)$ for control. The hospital mortality pooling both IL-6 receptor antagonists was $27.3 \%$ (108/395). Compared with control, median adjusted odds ratios for hospital survival were 1.64 (95\% Crl 1.14, 2.35) for tocilizumab and $2.01(95 \% \mathrm{Crl} 1.18,4.71)$ for sarilumab, yielding $99.6 \%$ and $99.5 \%$ posterior probabilities of superiority. The sensitivity analyses were consistent with the primary analysis (Tables S1 and S2). Of note, the estimates of the treatment effect for patients treated either with tocilizumab or sarilumab and corticosteroids in combination were greater than for any intervention on its own (Tables S3 and S4), suggesting benefit of 
medRxiv preprint doi: https://doi.org/10.1101/2021.01.07.21249390; this version posted January 9, 2021. The copyright holder for this preprint (which was not certified by peer review) is the author/funder, who has granted medRxiv a license to display the preprint in It is made available under a CC-BY-NC-ND 4.0 International license .

using both IL6 receptor antagonists and corticosteroids together in this critically ill population.

\section{Secondary Outcomes}

The secondary outcomes are listed in Table 2 and Figure 3. Tocilizumab and sarilumab were effective across all secondary outcomes, including 90-day survival, time to ICU and hospital discharge, and improvement in the World Health Organization (WHO) ordinal scale at day 14. ${ }^{16}$ Similar effects were seen in all CRP subgroups (Table S1).

There were nine serious adverse events reported in the tocilizumab group including one secondary bacterial infection, five bleeds, two cardiac events and one deterioration in vision. There were 11 serious adverse events in the control group, four bleeds and seven thromboses; and no serious adverse events in the sarilumab group. 
medRxiv preprint doi: https://doi.org/10.1101/2021.01.07.21249390; this version posted January $9,2021$. The copyright holder for this preprint (which was not certified by peer review) is the author/funder, who has granted medRxiv a license to display the preprint in It is made available under a CC-BY-NC-ND 4.0 International license .

\section{Discussion}

We show that in critically ill patients with Covid-19 the IL-6 receptor antagonists, tocilizumab and sarilumab, are both effective compared with current standard of care, which included corticosteroids in the majority of patients (>80\%). Benefit was consistent across primary and secondary outcomes, and across subgroups and secondary analyses.

Multiple observational and ex-vivo laboratory studies have demonstrated that IL-6 is an important cytokine associated with disease severity and mortality. ${ }^{17-19} \mathrm{~A}$ recent genomic analysis of critically ill patients with Covid-19, demonstrated that genetic variants in the IL-6 inflammatory pathway may have a causal link to life-threatening disease. ${ }^{20}$ There is therefore a good rationale to support inhibiting IL-6 pathways in severe Covid-19.

Our study should be compared with other trials of IL-6 receptor antagonists in Covid-19. Many previously reported trials included less severely ill patients and excluded patients already receiving respiratory support. ${ }^{6-8}$ In those studies, there was no clear evidence that tocilizumab was effective at preventing disease progression, and no evidence of benefit on survival, although they may have lacked power to detect differences in patient-centered outcomes. The EMPACTA trial reported that patients treated with tocilizumab were less likely to progress to need mechanical ventilation or to die by day 28 (hazard ratio 0.56 , $95 \% \mathrm{Cl} 0.32,0.97)$, although there was no difference in overall mortality (risk difference $2.0 \%, 95 \% \mathrm{Cl}-5.2 \%, 7.8 \%) .{ }^{9}$ The COVACTA trial included about $38 \%$ mechanically ventilated patients. It reported no difference in clinical status or mortality at day 28 , although the time to hospital discharge was shorter with tocilizumab (hazard ratio $1.35,95 \% \mathrm{Cl} 1.02,1.79$ ).${ }^{10} \mathrm{~A}$ 
medRxiv preprint doi: https://doi.org/10.1101/2021.01.07.21249390; this version posted January 9, 2021. The copyright holder for this preprint (which was not certified by peer review) is the author/funder, who has granted medRxiv a license to display the preprint in It is made available under a CC-BY-NC-ND 4.0 International license .

trial of sarilumab reported no benefit in the whole population but a trend towards reduced mortality in the critically ill group. ${ }^{21}$ We saw both an improved time to clinical improvement as well as a reduction in mortality. It is therefore possible that the maximum benefit from IL6 inhibition is seen in the most severely ill patients with Covid-19. However, it is important to note that in our trial, patients had to be enrolled within 24 hours after starting organ support. This may be an important factor to maximize effectiveness; treating critically ill patients early, while any developing organ dysfunction may be more reversible.

Investigators have proposed using CRP or other inflammatory markers to select patients with a hyperinflammatory state for treatment. ${ }^{6,8}$ We saw beneficial effects of IL-6 inhibition across all CRP subgroups in this critically ill population. Although Covid-19 has been described as producing a "cytokine storm",22 recent studies have shown that systemic levels of cytokines may not be as high as seen in other causes of sepsis and ARDS. ${ }^{23}$ It may be that local inflammation, demonstrated by respiratory dysfunction, is a more useful indicator of which patients will benefit from IL-6 inhibition. There has been concern about administering immune modulating drugs, such as tocilizumab and sarilumab, to patients critically ill due to a novel virus infection. One consistent result across all trials to date, including our trial, is there has been no increased rates of serious adverse events reported.

REMAP-CAP's pragmatic, international design means that our results are likely generalizable to the wider critically ill patient population with Covid-19. It, of course, has limitations. Most notably, it uses an open-label design but awareness of intervention assignment is unlikely to affect the primary outcome. Furthermore, as IL-6 inhibition is known to have a profound effect on CRP, ${ }^{24,25}$ even if the study drug was blinded, intervention assignment would 
medRxiv preprint doi: https://doi.org/10.1101/2021.01.07.21249390; this version posted January 9, 2021. The copyright holder for this preprint (which was not certified by peer review) is the author/funder, who has granted medRxiv a license to display the preprint in It is made available under a CC-BY-NC-ND 4.0 International license.

become "revealed" rapidly after administration. As this is an early, preliminary report some data are missing including 11 outcomes. Some patients still remain in hospital and so longterm outcomes may differ from the short-term outcomes presented here. The multifactorial design also allows multiple different interventions to be evaluated simultaneously, providing more efficient results and accounting for potential treatment-by-treatment interactions. Many of these interventions continue, and their effects and possible interactions are still to be reported.

In conclusion, in critically ill adult patients with Covid-19 receiving organ support in intensive care, treatment with the IL-6 receptor antagonists, tocilizumab and sarilumab, improved outcomes, including survival. 
medRxiv preprint doi: https://doi.org/10.1101/2021.01.07.21249390; this version posted January 9, 2021. The copyright holder for this preprint (which was not certified by peer review) is the author/funder, who has granted medRxiv a license to display the preprint in It is made available under a CC-BY-NC-ND 4.0 International license .

\section{Acknowledgements:}

Funding: The Platform for European Preparedness Against (Re-) emerging Epidemics (PREPARE) consortium by the European Union, FP7-HEALTH-2013-INNOVATION-1 (\#602525), the Rapid European COVID-19 Emergency Research response (RECOVER) consortium by the European Union's Horizon 2020 research and innovation programme (\#101003589), the Australian National Health and Medical Research Council (\#APP1101719), the Health Research Council of New Zealand (\#16/631), and the Canadian Institute of Health Research Strategy for Patient-Oriented Research Innovative Clinical Trials Program Grant (\#158584), the UK National Institute for Health Research (NIHR) and the NIHR Imperial Biomedical Research Centre, the Health Research Board of Ireland (CTN 2014-012), the UPMC Learning While Doing Program, the Breast Cancer Research Foundation, the French Ministry of Health (PHRC-20-0147), the Minderoo Foundation and the Wellcome Trust Innovations Project (215522). ACG is funded by an NIHR Research Professorship (RP-201506-18) and MSH by an NIHR Clinician Scientist Fellowship (CS-2016-16-011).

The views expressed in this publication are those of the author(s) and not necessarily those of the NHS, the National Institute for Health Research or the Department of Health and Social Care.

Support: We are grateful to the NIHR Clinical Research Network (UK), UPMC Health System Health Services Division (US), and the Direction de la Recherche Clinique et de I'Innovation de l'AP-HP (France) for their support of participant recruitment. We are grateful for the supply of study drugs in the United Kingdom from Roche Products Ltd and Sanofi (Aventis Pharma Ltd). 
medRxiv preprint doi: https://doi.org/10.1101/2021.01.07.21249390; this version posted January 9, 2021. The copyright holder for this preprint (which was not certified by peer review) is the author/funder, who has granted medRxiv a license to display the preprint in It is made available under a CC-BY-NC-ND 4.0 International license .

\section{Figure 1. Screening, enrollment, randomization and inclusion in analysis}

$\mathrm{a}=$ Patients could meet more than one ineligibility criterion. Full details are provided in the supplement

$b=$ only includes patients when tocilizumab and /or sarilumab was a randomization option $c=$ other interventions includes anakinra, interferon $\beta 1 a$, and no immune modulation when tocilizumab and / or sarilumab was not available as a randomization option $d=$ The primary analysis of alternative interventions within the immune modulation domain is estimated from a model that adjusts for patient factors and for assignment to interventions in other domains. To obtain the most reliable estimation of the effect of these patient factors and of other interventions on the primary outcome, all patients enrolled in the severe COVID-19 cohort (for whom there is consent and follow-up) are included. Importantly, however, the model also factors eligibility for the immune modulation domain and its interventions, such that the final estimate of an immune modulation domain intervention's effectiveness relative to any other within that domain is generated from those patients that might have been eligible to be randomized to those interventions within the domain.

$\wedge$ Contraindications include hypersensitivity, raised ALT/AST, or thrombocytopenia, or pregnancy

\section{Figure 2. Distributions of organ support-free days.}

Panel A) the cumulative proportion ( $y$-axis) for each intervention group by day (x-axis), with death listed first. Curves that rise more slowly are more favorable. Panel B) Organ supportfree days as horizontally stacked proportions by intervention group. Red represents worse outcomes and blue represents better outcomes. The median adjusted odds ratios from the 
medRxiv preprint doi: https://doi.org/10.1101/2021.01.07.21249390; this version posted January 9, 2021. The copyright holder for this preprint (which was not certified by peer review) is the author/funder, who has granted medRxiv a license to display the preprint in It is made available under a CC-BY-NC-ND 4.0 International license .

primary analysis, using a Bayesian cumulative logistic model, were 1.64 (95\% credible interval, 1.25 to 2.14 ) and 1.76 (95\% credible interval, 1.17 to 2.91 ) for the tocilizumab and sarilumab groups compared with control, yielding $>99.9 \%$ and $99.5 \%$ probabilities of superiority compared with control, respectively.

Panels C) and D) are similar figures with the tocilizumab and sarilumab interventions pooled together. The median adjusted odds ratio is 1.65 (95\% credible interval 1.27 to 2.14$)$ yielding $>99.9 \%$ probability of superiority compared with control.

Figure 3. Time to event analyses.

Shown are Kaplan-Meier curves for survival by individual intervention group (Panel A), survival with tocilizumab and sarilumab intervention groups pooled together (Panel B), time to intensive care unit discharge by individual intervention group (Panel C) and time to hospital discharge by individual intervention group (Panel D) 
medRxiv preprint doi: https://doi.org/10.1101/2021.01.07.21249390; this version posted January 9, 2021. The copyright holder for this preprint (which was not certified by peer review) is the author/funder, who has granted medRxiv a license to display the preprint in It is made available under a CC-BY-NC-ND 4.0 International license .

Table 1. Baseline Characteristics of Participants in the Immune Modulation Therapy domain*

\begin{tabular}{|c|c|c|c|c|}
\hline Characteristic & $\begin{array}{l}\text { Tocilizumab } \\
(\mathrm{N}=353)\end{array}$ & $\begin{array}{l}\text { Sarilumab } \\
(\mathrm{N}=48)\end{array}$ & $\begin{array}{l}\text { Control }^{a} \\
(\mathrm{~N}=402)\end{array}$ & $\begin{array}{l}\text { All participants in } \\
\text { the Immune } \\
\text { Modulation } \\
\text { Therapy domain } \\
\text { (N=865) }\end{array}$ \\
\hline Age - mean (SD), years & $61.5(12.5)$ & $63.4(13.4)$ & $61.1(12.8)$ & $61.4(12.7)$ \\
\hline Male Sex - n (\%) & 261 (73.9) & $39(81.3)$ & $283(70.4)$ & $629(72.7)$ \\
\hline $\begin{array}{l}\text { Race/Ethnicity }{ }^{c} \text { - } \\
\text { White - n/N (\%) }\end{array}$ & $160 / 228(70.2)$ & 29/39 (74.4) & $206 / 279(73.8)$ & $420 / 580(72.4)$ \\
\hline Asian - $\mathrm{n} / \mathrm{N}(\%)$ & $41 / 228$ (18.0) & $8 / 39(20.5)$ & $47 / 279$ (16.9) & $99 / 580(17.1)$ \\
\hline Black - n/N (\%) & $12 / 228(5.3)$ & $1 / 39(2.6)$ & $9 / 279(3.2)$ & $23 / 580(4.0)$ \\
\hline Mixed - n/N (\%) & $2 / 228(0.9)$ & $0 / 39(0.0)$ & $5 / 279(1.8)$ & $7 / 580(1.2)$ \\
\hline Other - $\mathrm{n} / \mathrm{N}(\%)$ & $13 / 228(5.7)$ & $1 / 39(2.6)$ & $12 / 279(4.3)$ & $31 / 580(5.3)$ \\
\hline $\begin{array}{l}\text { Body mass index }{ }^{d} \text { - median } \\
(I Q R), k g / m^{2}\end{array}$ & $\begin{array}{l}30.5(26.9-34.9) \\
\quad(n=342)\end{array}$ & $\begin{array}{c}29.2(26.0-33.8) \\
(n=39)\end{array}$ & $\begin{array}{c}30.9(27.1-34.9) \\
(n=377)\end{array}$ & $\begin{array}{l}30.5(26.8-34.9) \\
\quad(n=815)\end{array}$ \\
\hline APACHE II score ${ }^{\mathbf{e}}$ - median (IQR) & $13(8-19)(n=337)$ & $10(7-16)(n=42)$ & $12(8-18)(n=381)$ & $12.5(8-19)(n=820)$ \\
\hline $\begin{array}{l}\text { Confirmed SARS-CoV2 infection } \\
-n / N(\%)\end{array}$ & $284 / 345(82.3)$ & $44 / 47$ (93.6) & $334 / 394(84.8)$ & $715 / 847(84.4)$ \\
\hline \multicolumn{5}{|l|}{$\begin{array}{l}\text { Pre-existing conditions }-\mathrm{n} / \mathrm{N} \\
(\%)\end{array}$} \\
\hline Diabetes mellitus & $123 / 349(35.2)$ & $13 / 48(27.1)$ & $150 / 401(37.4)$ & $304 / 860(35.4)$ \\
\hline Kidney disease & $30 / 312(9.6)$ & $4 / 45(8.9)$ & $43 / 372(11.6)$ & $81 / 789$ (10.3) \\
\hline Respiratory disease $\not$ & $82 / 349(23.5)$ & $15 / 48(31.3)$ & $98 / 401(24.4)$ & $206 / 860(24.0)$ \\
\hline Immunosuppressive disease & $8 / 348(2.3)$ & $0 / 48(0.0)$ & $14 / 401$ (3.5) & $25 / 859$ (2.9) \\
\hline $\begin{array}{l}\text { Chronic immunosuppressive } \\
\text { therapy }\end{array}$ & $3 / 349(0.9)$ & $1 / 48(2.1)$ & $6 / 401(1.5)$ & $12 / 860(1.4)$ \\
\hline Severe cardiovascular disease & $34 / 339(10.0)$ & $1 / 48(2.1)$ & 47/395 (11.9) & $86 / 844(10.2)$ \\
\hline Liver cirrhosis/failure & $2 / 339(0.6)$ & $0 / 48(0.0)$ & $1 / 395(0.3)$ & $5 / 844(0.6)$ \\
\hline \multicolumn{5}{|l|}{$\begin{array}{l}\text { Time to enrollment - median } \\
\text { (IQR) }\end{array}$} \\
\hline $\begin{array}{l}\text { From hospital admission - } \\
\text { days }\end{array}$ & $1.2(0.8-2.8)$ & $1.4(0.9-2.8)$ & $1.2(0.8-2.8)$ & $1.2(0.8-2.8)$ \\
\hline From ICU admission - hours & $13.1(6.6-19.0)$ & $16.0(11.4-20.8)$ & $14.0(6.8-19.5)$ & $13.6(6.6-19.4)$ \\
\hline \multicolumn{5}{|l|}{ Acute respiratory support } \\
\hline $\begin{array}{l}\text { None/supplemental oxygen } \\
\text { only }\end{array}$ & $1 / 353(0.3)$ & $0 / 48(0.0)$ & $2 / 402(0.5)$ & $3 / 865(0.4)$ \\
\hline High flow nasal cannula & $101 / 353(28.6)$ & $17 / 48(35.4)$ & $110 / 402(27.4)$ & $249 / 865(28.8)$ \\
\hline
\end{tabular}


medRxiv preprint doi: https://doi.org/10.1101/2021.01.07.21249390; this version posted January 9,2021 . The copyright holder for this preprint (which was not certified by peer review) is the author/funder, who has granted medRxiv a license to display the preprint in It is made available under a CC-BY-NC-ND 4.0 International license .

\begin{tabular}{|c|c|c|c|c|}
\hline Non-invasive ventilation only & $147 / 353(41.6)$ & $23 / 48$ (47.9) & $169 / 402(42.0)$ & $359 / 865(41.5)$ \\
\hline $\begin{array}{l}\text { Invasive mechanical } \\
\text { ventilation }\end{array}$ & $104 / 353(29.5)$ & $8 / 48(16.7)$ & $121 / 402(30.1)$ & $254 / 865(29.4)$ \\
\hline Vasopressor support & 63/353 (17.9) & $4 / 48(8.3)$ & 79/402 (19.7) & $163 / 865(18.8)$ \\
\hline $\mathrm{PaO}_{2} / \mathrm{FIO}_{2}$ - median (IQR) & $\begin{array}{c}115(89-162) \\
(n=335)\end{array}$ & $126(99-157)$ & $\begin{array}{c}118(89-169) \\
(n=354)\end{array}$ & $\begin{array}{c}116.5(89-165) \\
(n=780)\end{array}$ \\
\hline \multicolumn{5}{|l|}{$\begin{array}{l}\text { Median laboratory values } \\
(\text { IQR })^{\mathrm{g}}\end{array}$} \\
\hline C-reactive protein, $\mu \mathrm{g} / \mathrm{mL}$ & $\begin{array}{c}150(85-221) \\
(n=207)\end{array}$ & $\begin{array}{c}136(105-204) \\
(n=37)\end{array}$ & $\begin{array}{c}130(71-208) \\
(n=244)\end{array}$ & $\begin{array}{c}136(79-208) \\
\quad(n=533)\end{array}$ \\
\hline D-dimer, ng/mL & $\begin{array}{c}832(461-1763) \\
(n=159)\end{array}$ & $\begin{array}{c}828(355-1435) \\
(n=20)\end{array}$ & $\begin{array}{c}1010(500-2115) \\
(n=172)\end{array}$ & $\begin{array}{c}910(480-1916) \\
(n=385)\end{array}$ \\
\hline Ferritin, ng/mL & $\begin{array}{l}912(525-1590) \\
\quad(n=201)\end{array}$ & $\begin{array}{c}1914(696-2315) \\
(n=13)\end{array}$ & $\begin{array}{c}887(410-1573) \\
(n=199)\end{array}$ & $\begin{array}{c}929(472-1643) \\
(n=447)\end{array}$ \\
\hline Neutrophils, x109/L & $\begin{array}{c}8(5.8-10.7) \\
(n=239)\end{array}$ & $\begin{array}{c}7.7(5.4-10.2) \\
\quad(n=47)\end{array}$ & $\begin{array}{c}7.9(5.3-11.0) \\
(n=278)\end{array}$ & $\begin{array}{c}7.9(5.6-10.7) \\
(n=612)\end{array}$ \\
\hline Lymphocytes, x109/L & $\begin{array}{l}0.7(0.5-1.0) \\
\quad(n=239)\end{array}$ & $\begin{array}{l}0.6(0.4-0.9) \\
\quad(n=47)\end{array}$ & $\begin{array}{l}0.7(0.5-1.0) \\
\quad(n=279)\end{array}$ & $\begin{array}{l}0.7(0.5-1.0) \\
\quad(n=613)\end{array}$ \\
\hline Platelets, $\times 10^{9} / \mathrm{L}$ & $\begin{array}{c}250(183-323) \\
\quad(n=346)\end{array}$ & $\begin{array}{c}273(205-319) \\
\quad(n=48)\end{array}$ & $\begin{array}{c}236(177-297) \\
\quad(n=398)\end{array}$ & $\begin{array}{c}245(182-311) \\
\quad(n=854)\end{array}$ \\
\hline Lactate, $\mathrm{mmol} / \mathrm{L}$ & $\begin{array}{c}1.3(1.0-1.8) \\
(n=303)\end{array}$ & $\begin{array}{c}1.5(1.2-2.0) \\
\quad(n=40)\end{array}$ & $\begin{array}{c}1.4(1.0-1.9) \\
(n=353)\end{array}$ & $\begin{array}{l}1.4(1.0-1.9) \\
\quad(n=754)\end{array}$ \\
\hline Creatinine, mg/dL & $\begin{array}{c}0.8(0.7-1.2) \\
(n=348)\end{array}$ & $\begin{array}{c}1.0(0.6-1.4) \\
\quad(n=48)\end{array}$ & $\begin{array}{c}0.9(0.7-1.2) \\
(n=398)\end{array}$ & $\begin{array}{l}0.9(0.7-1.2) \\
\quad(n=856)\end{array}$ \\
\hline Bilirubin, $\mathrm{mg} / \mathrm{dL}$ & $\begin{array}{c}0.11(0.08-0.15) \\
(n=327)\end{array}$ & $\begin{array}{c}0.11(0.09-0.18) \\
(n=46)\end{array}$ & $\begin{array}{c}0.10(0.08-0.15) \\
(n=382)\end{array}$ & $\begin{array}{c}0.11(0.08-0.15) \\
(n=817)\end{array}$ \\
\hline
\end{tabular}

* Percentages may not sum to 100 because of rounding. SD denotes standard deviation; APACHE, Acute Physiology and Chronic Health Evaluation; COPD, chronic obstructive pulmonary disease; IQR, interquartile range; ECMO, extracorporeal membrane oxygenation.

${ }^{a}$ Control patients include all patient randomized to control who were also eligible to be randomized to tocilizumab and/or sarilumab.

${ }^{b}$ All patients includes patient randomized in the Immune Modulation Therapy domain, including control (including where tocilizumab and sarilumab were not a randomization option), tocilizumab, sarilumab, anakinra and interferon-beta-1a.

" Data collection not approved in Canada and continental Europe. "Other" includes "declined" and "multiple".

${ }^{d}$ The body-mass index (BMI) is the weight in kilograms divided by the square of the height in meters.

e Range 0 to 71, with higher scores indicating greater severity of illness.

f SARS-CoV2 infection was confirmed by respiratory tract polymerase chain reaction test

${ }^{g}$ Values were from the sample collected closest to randomization, up to 8 hours prior to randomization. If no samples were collected up to 8 hours prior to time of randomization, the sample collected closest to the time of randomization up to 2 hours after randomization was used (other than $\mathrm{PaO}_{2} / \mathrm{FlO}_{2}$ which was a prerandomization value only). Laboratory values were only added to the case report form on August 6, 2020. 
medRxiv preprint doi: https://doi.org/10.1101/2021.01.07.21249390; this version posted January 9, 2021. The copyright holder for this preprint (which was not certified by peer review) is the author/funder, who has granted medRxiv a license to display the preprint in

It is made available under a CC-BY-NC-ND 4.0 International license .

Table 2. Primary and Secondary Outcomes.

\begin{tabular}{|c|c|c|c|}
\hline Outcome/Analysis & Tocilizumab (N=353) & Sarilumab ( $N=48)$ & Control $(\mathrm{N}=402)$ \\
\hline \multicolumn{4}{|l|}{$\begin{array}{l}\text { Primary Outcome, Organ support-free days } \\
\text { (OSFDs) }\end{array}$} \\
\hline Median (IQR) & $10(-1$ to 16$)$ & 11 (0 to 16$)$ & $0(-1$ to 15$)$ \\
\hline Adjusted OR - mean (SD) & $1.65(0.23)$ & $1.83(0.44)$ & 1 \\
\hline - median (95\% Crl) & 1.64 (1.25 to 2.14$)$ & 1.76 (1.17 to 2.91$)$ & 1 \\
\hline Probability of superiority to control, $\%$ & $>99.9$ & 99.5 & - \\
\hline \multicolumn{4}{|l|}{ Subcomponents of OSFDs } \\
\hline In-hospital deaths, n (\%) & $98 / 350(28.0)$ & $10 / 45(22.2)$ & $142 / 397(35.8)$ \\
\hline OSFDs in survivors, median (IQR) & 14 (7 to 17$)$ & 15 (6.5 to 17$)$ & 13 (4 to 17$)$ \\
\hline \multicolumn{4}{|l|}{ Primary Hospital Survival, } \\
\hline Adjusted OR - mean (SD) & $1.66(0.31)$ & $2.25(0.96)$ & 1 \\
\hline - median (95\% Crl) & 1.64 (1.14 to 2.35$)$ & 2.01 (1.18 to 4.71$)$ & 1 \\
\hline Probability of superiority to control, $\%$ & 99.6 & 99.5 & - \\
\hline \multicolumn{4}{|c|}{$\begin{array}{l}\text { Secondary Analysis of Primary Outcome, model } \\
\text { restricted to Immune Modulation Therapy domain } \\
\text { patients and other closed domains }\end{array}$} \\
\hline Adjusted OR - mean (SD) & $1.68(0.24)$ & $1.84(0.44)$ & 1 \\
\hline - median (95\% Crl) & 1.66 (1.26 to 2.18$)$ & 1.77 (1.18 to 2.90$)$ & 1 \\
\hline Probability of superiority to control, $\%$ & $>99.9$ & 99.6 & - \\
\hline \multicolumn{4}{|c|}{$\begin{array}{l}\text { Secondary Analysis of Primary Hospital Survival, } \\
\text { model restricted to Immune Modulation Therapy } \\
\text { domain patients and other closed domains }\end{array}$} \\
\hline Adjusted OR - mean (SD) & $1.67(0.31)$ & 2.24 & 1 \\
\hline - median (95\% Crl) & 1.65 (1.15 to 2.34$)$ & 2.00 (1.17 to 4.69$)$ & 1 \\
\hline Probability of superiority to control, $\%$ & 99.6 & 99.4 & - \\
\hline \multicolumn{4}{|l|}{ Other Secondary Outcomes } \\
\hline \multicolumn{4}{|l|}{ 90-day Survival (time to event) } \\
\hline Adjusted HR - mean (SD) & $1.60(0.21)$ & $1.94(0.56)$ & 1 \\
\hline - median (95\% Crl) & 1.59 (1.24 to 2.05$)$ & 1.82 (1.22 to 3.38$)$ & 1 \\
\hline Probability of superiority to control, \% & $>99.9$ & 99.8 & - \\
\hline \multicolumn{4}{|l|}{ Respiratory support-free days } \\
\hline Adjusted OR - mean (SD) & $1.74(0.25)$ & $2.04(0.53)$ & 1 \\
\hline - median (95\% Crl) & 1.73 (1.31 to 2.27 ) & 1.94 (1.27 to 3.32$)$ & 1 \\
\hline Probability of superiority to control, $\%$ & $>99.9$ & 99.9 & - \\
\hline \multicolumn{4}{|l|}{ Cardiovascular support-free days } \\
\hline Adjusted OR - mean (SD) & $1.70(0.26)$ & $1.95(0.53)$ & 1 \\
\hline - median (95\% Crl) & 1.68 (1.25 to 2.24$)$ & 1.85 (1.20 to 3.30$)$ & 1 \\
\hline Probability of superiority to control, \% & $>99.9$ & 99.5 & - \\
\hline \multicolumn{4}{|l|}{ Time to ICU discharge } \\
\hline Adjusted HR - mean (SD) & $1.43(0.13)$ & $1.69(0.32)$ & 1 \\
\hline - median (95\% Crl) & 1.42 (1.18 to 1.70$)$ & 1.64 (1.21 to 2.45$)$ & 1 \\
\hline Probability of superiority to control, \% & $>99.9$ & 99.9 & - \\
\hline
\end{tabular}


medRxiv preprint doi: https://doi.org/10.1101/2021.01.07.21249390; this version posted January 9, 2021. The copyright holder for this preprint (which was not certified by peer review) is the author/funder, who has granted medRxiv a license to display the preprint in It is made available under a CC-BY-NC-ND 4.0 International license.

\begin{tabular}{|c|c|c|c|}
\hline \multicolumn{4}{|l|}{ Time to hospital discharge } \\
\hline Adjusted HR - mean (SD) & $1.42(0.13)$ & $1.65(0.31)$ & 1 \\
\hline - median (95\% Crl) & 1.41 (1.18 to 1.70$)$ & 1.60 (1.17 to 2.40$)$ & 1 \\
\hline Probability of superiority to control, \% & $>99.9$ & 99.8 & - \\
\hline \multicolumn{4}{|l|}{ WHO scale at day 14} \\
\hline Adjusted OR - mean (SD) & $1.85(0.26)$ & $1.91(0.43)$ & 1 \\
\hline - median (95\% Crl) & 1.83 (1.40 to 2.41$)$ & $1.86(1.22$ to 2.91$)$ & 1 \\
\hline Probability of superiority to control, $\%$ & $>99.9$ & 99.6 & - \\
\hline \multicolumn{4}{|c|}{$\begin{array}{l}\text { Progression to invasive mechanical ventilation, ECMO or death, } \\
\text { restricted to those not intubated at baseline }\end{array}$} \\
\hline $\begin{array}{l}\text { Free of invasive mechanical ventilation at } \\
\text { baseline, } n\end{array}$ & 242 & 37 & 273 \\
\hline Progression to intubation, ECMO or death, $\mathrm{n}(\%)$ & $100 / 242(41.3)$ & $13 / 37(35.1)$ & $144 / 273(52.7)$ \\
\hline Adjusted OR - mean (SD) & $1.72(0.33)$ & $1.82(0.55)$ & 1 \\
\hline - median (95\% Crl) & 1.69 (1.17 to 2.42$)$ & 1.74 (1.01 to 3.14$)$ & 1 \\
\hline Probability of superiority to control, $\%$ & 99.8 & 97.7 & - \\
\hline \multicolumn{4}{|l|}{ Serious Adverse Events } \\
\hline Patients with $\geq 1$ serious adverse event, $\mathrm{n}(\%)$ & $9 / 353(2.5)$ & $0 / 48(0.0)$ & $11 / 402(2.7)$ \\
\hline Adjusted OR - mean (SD) & $1.22(0.55)$ & $2.99(2.95)$ & 1 \\
\hline - median (95\% Crl) & 1.10 (0.48 to 2.58$)$ & 2.10 (0.51 to 10.77$)$ & 1 \\
\hline Probability of superiority to control, $\%$ & 59.3 & 84.0 & - \\
\hline
\end{tabular}

The primary analysis of organ support-free days (OSFD) and in-hospital mortality used data from all participants enrolled in the trial who met COVID-19 severe state criteria and were randomized within at least one domain ( $n=1928$ ), adjusting for age, sex, time period, site, region, domain and intervention eligibility and intervention assignment.

Other analyses were restricted to participants enrolled in the Immune Modulation domain and any domains that have ceased recruitment (Corticosteroid and Covid-19 Antiviral domains) ( $n=1293$ ), adjusting for age, sex, time period, site, region, domain and intervention eligibility and intervention assignment.

Definitions of outcomes are provided in Methods and the study protocol.

All models are structured such that a higher OR or HR is favorable. The WHO scale ranges from 0 (no disease) to 8 (death).

SD - standard deviation; Crl - credible interval; OR - odds ratio; HR - Hazard ratio. 
medRxiv preprint doi: https://doi.org/10.1101/2021.01.07.21249390; this version posted January 9, 2021. The copyright holder for this preprint (which was not certified by peer review) is the author/funder, who has granted medRxiv a license to display the preprint in

It is made available under a CC-BY-NC-ND 4.0 International license .

Figure 1

3,301 Patients admitted to ICU with suspected or proven COVID-19 disease assessed for eligibility between March 9th and November $19^{\text {th }}, 2020$

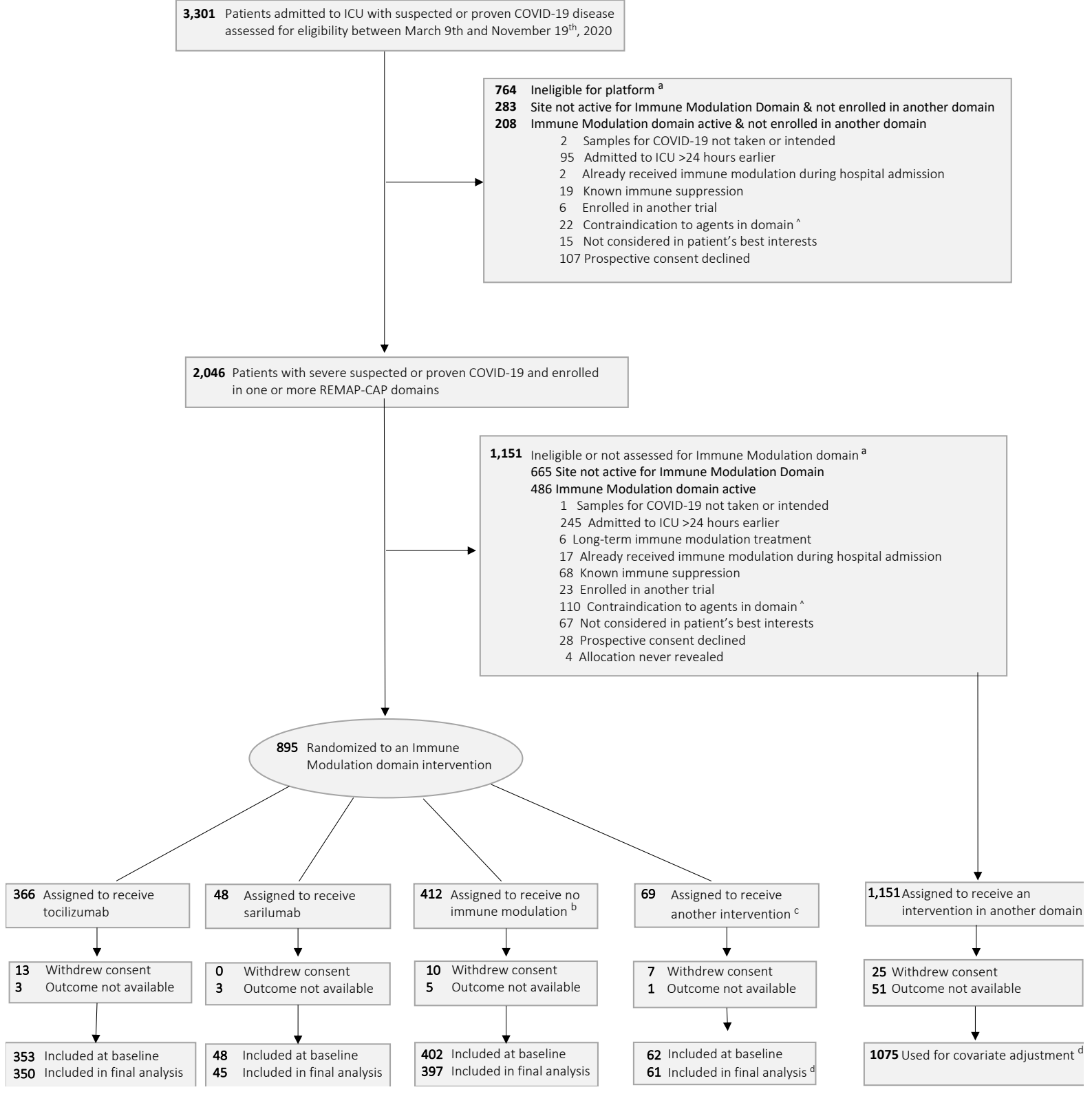


medRxiv preprint doi: https://doi.org/10.1101/2021.01.07.21249390; this version posted January 9, 2021. The copyright holder for this preprint (which was not certified by peer review) is the author/funder, who has granted medRxiv a license to display the preprint in It is made available under a CC-BY-NC-ND 4.0 International license

\section{Figure $2 \mathrm{~A}$}

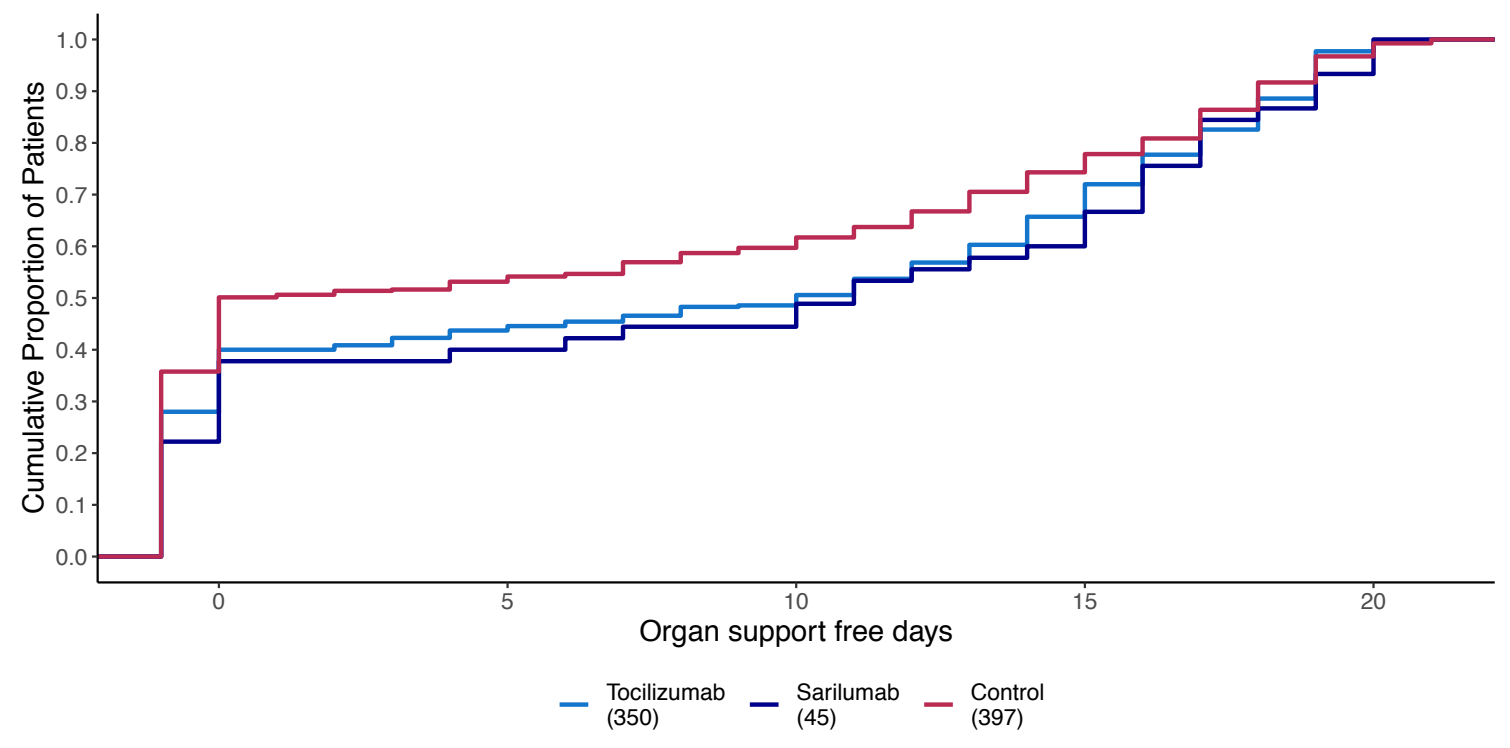

B

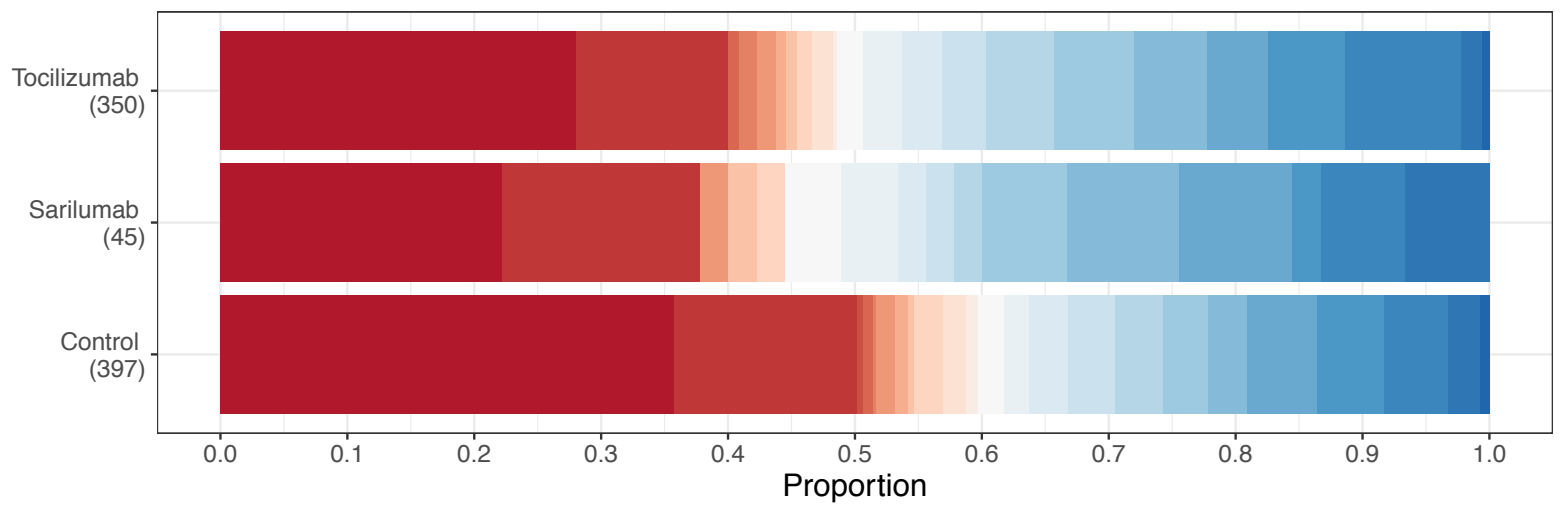

OSFD 
medRxiv preprint doi: https://doi.org/10.1101/2021.01.07.21249390; this version posted January 9, 2021. The copyright holder for this preprint (which was not certified by peer review) is the author/funder, who has granted medRxiv a license to display the preprint in It is made available under a CC-BY-NC-ND 4.0 International license

Figure $2 \mathrm{C}$

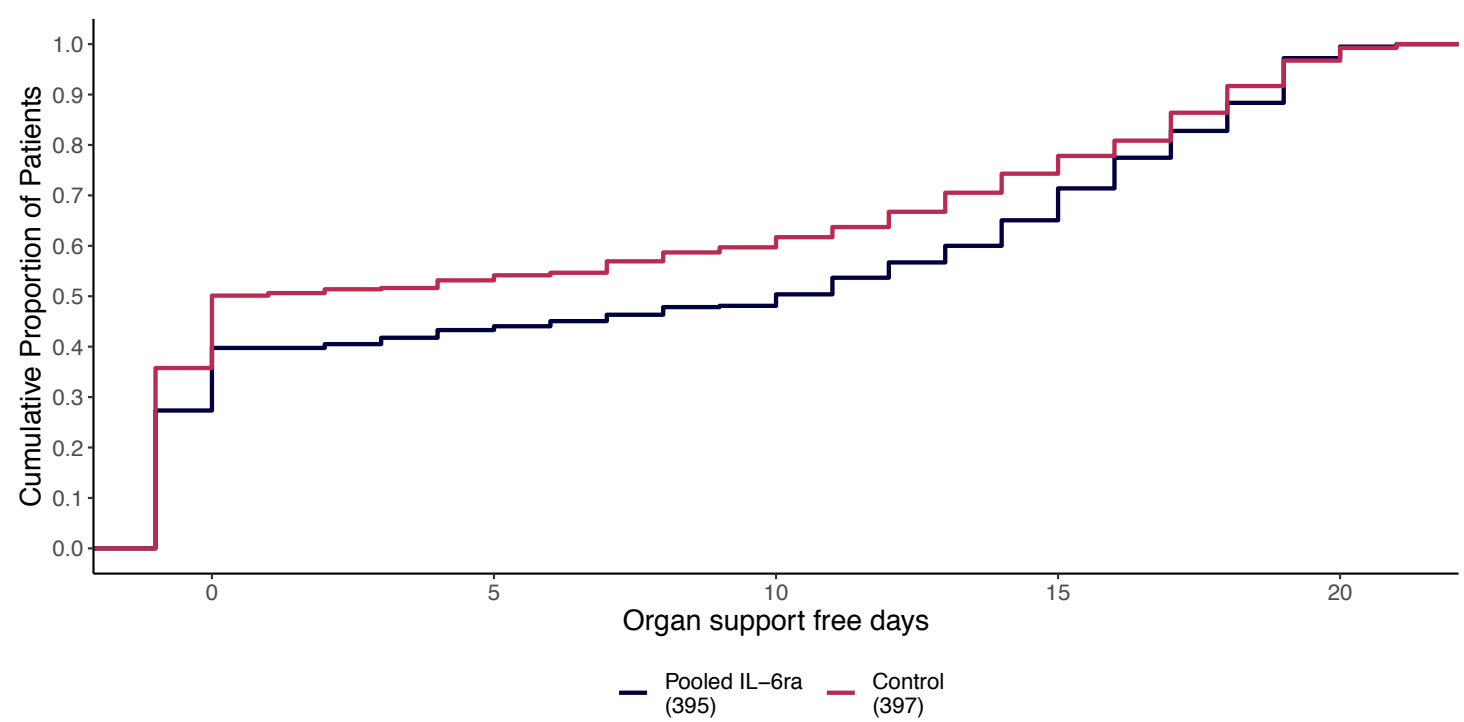

D

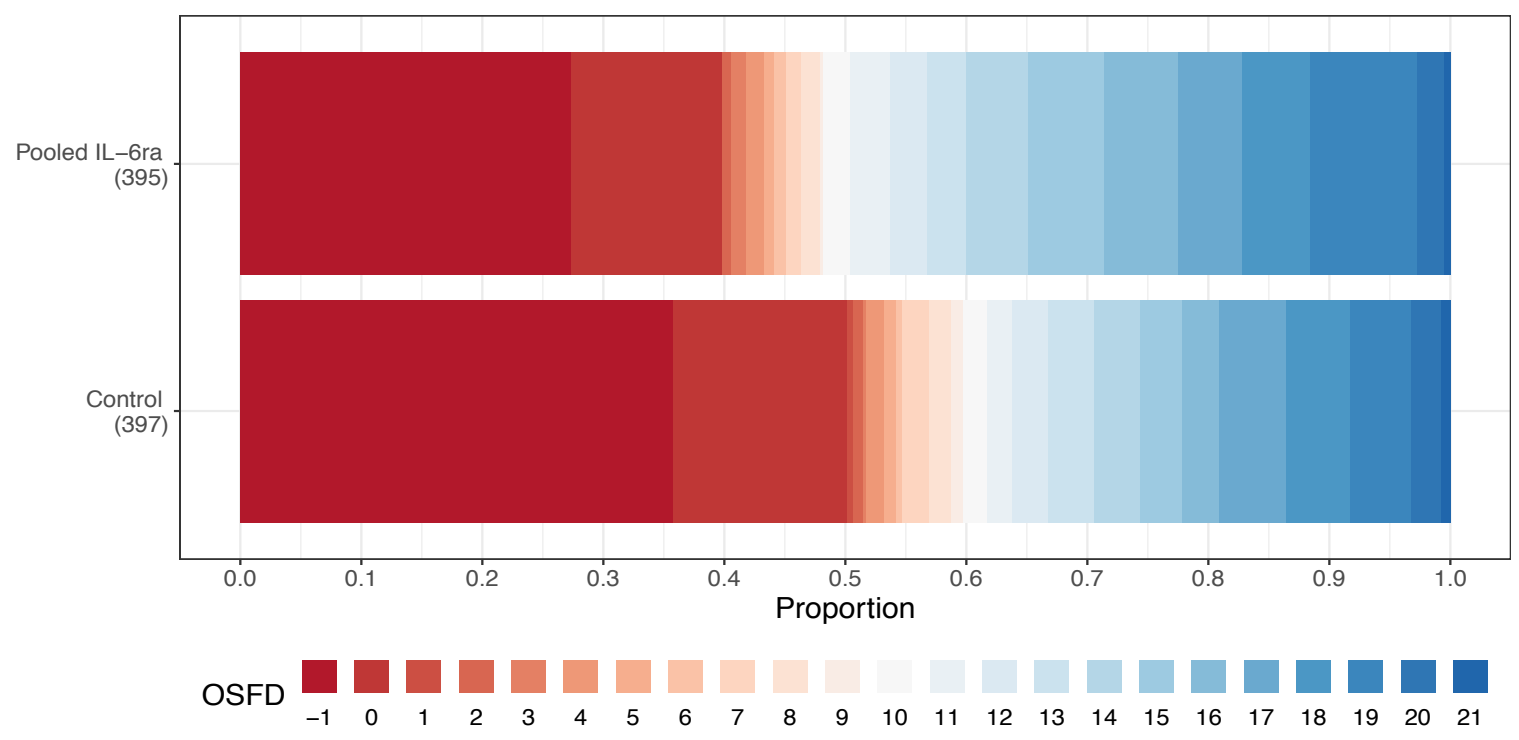


medRxiv preprint doi: https://doi.org/10.1101/2021.01.07.21249390; this version posted January 9, 2021. The copyright holder for this preprint (which was not certified by peer review) is the author/funder, who has granted medRxiv a license to display the preprint in It is made available under a CC-BY-NC-ND 4.0 International license .

\section{Figure 3}

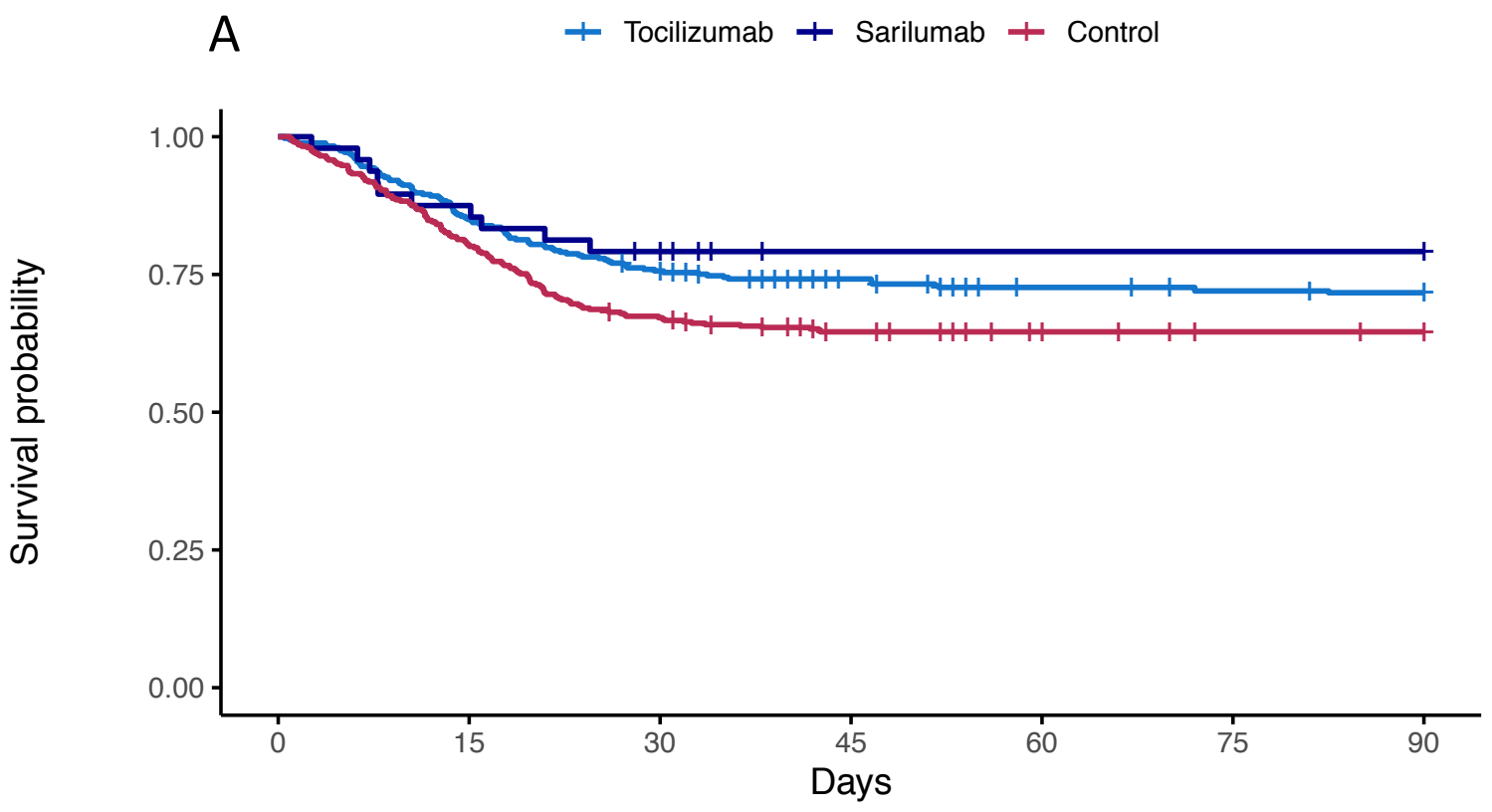

Number at risk

\begin{tabular}{rccccccc} 
Tocilizumab - & 353 & 300 & 266 & 242 & 230 & 226 & 224 \\
Sarilumab & 48 & 42 & 37 & 31 & 31 & 31 & 31 \\
Control & 402 & 323 & 268 & 242 & 231 & 226 & 225 \\
\hline & 15 & 30 & 45 & 60 & 75 & 90
\end{tabular}

B $\quad+$ Pooled IL-6ra + Control

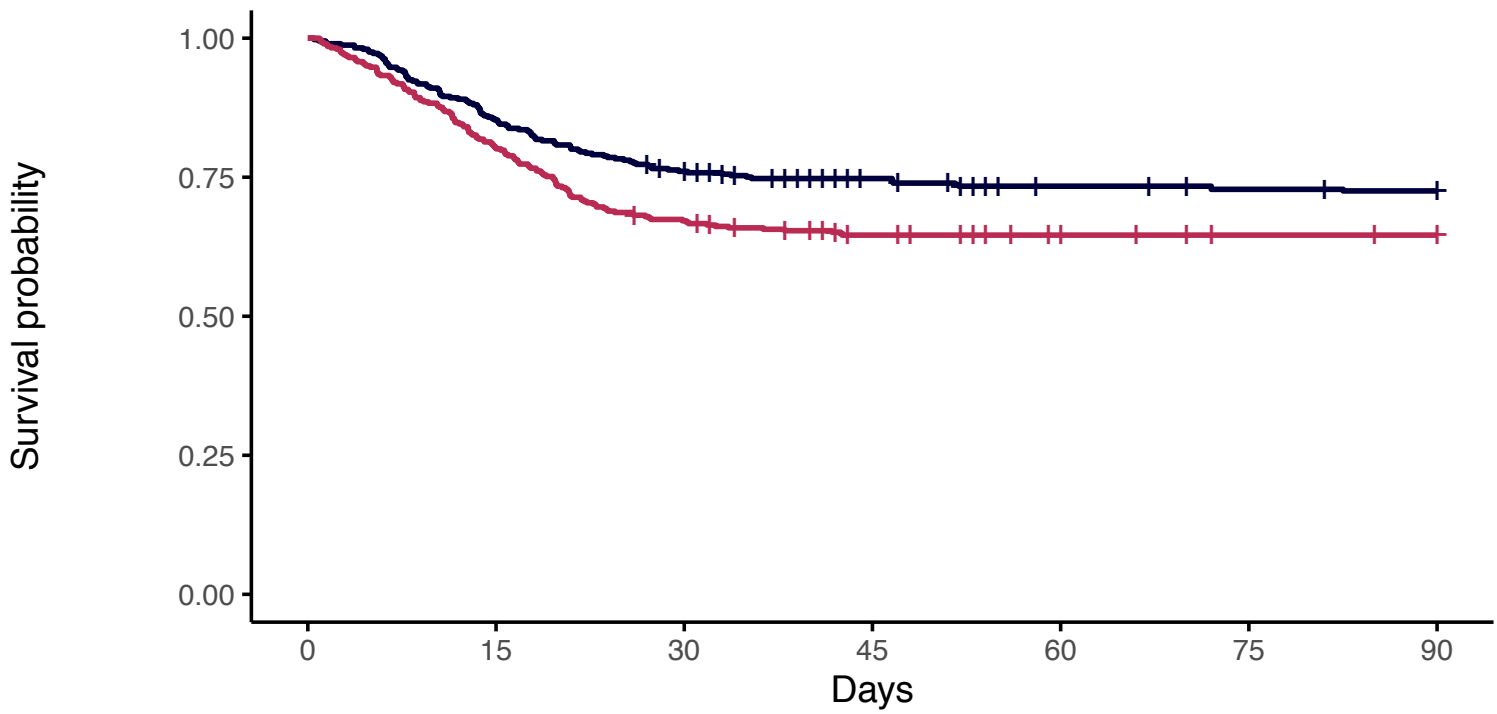

Number at risk

\begin{tabular}{|c|c|c|c|c|c|c|c|}
\hline Pooled IL-6ra & 401 & 342 & 303 & 273 & 261 & 257 & 255 \\
\hline Control - & 402 & 323 & 268 & 242 & 231 & 226 & 225 \\
\hline & 0 & 15 & 30 & $\begin{array}{c}45 \\
\text { Days }\end{array}$ & 60 & 75 & 90 \\
\hline
\end{tabular}


medRxiv preprint doi: https://doi.org/10.1101/2021.01.07.21249390; this version posted January 9, 2021. The copyright holder for this preprint (which was not certified by peer review) is the author/funder, who has granted medRxiv a license to display the preprint in It is made available under a CC-BY-NC-ND 4.0 International license .

\section{Figure 3}

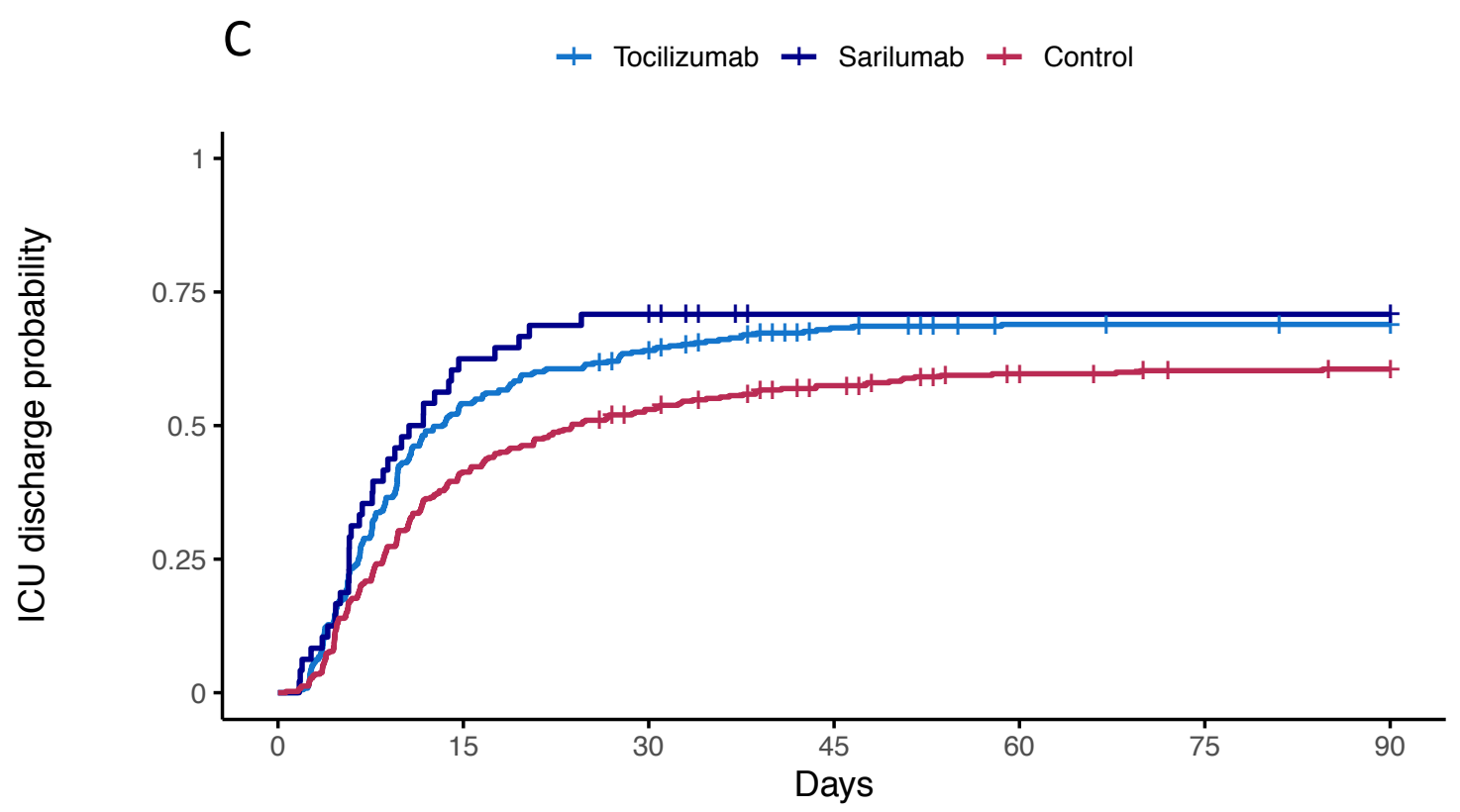

Number at risk

\begin{tabular}{r|ccccccc} 
Tocilizumab & 353 & 162 & 125 & 99 & 91 & 90 & 89 \\
Sarilumab & 48 & 18 & 14 & 7 & 7 & 7 & 7 \\
Control & 402 & 236 & 184 & 157 & 140 & 134 & 132 \\
\hline & 15 & 15 & 30 & 45 & 60 & 75 & 90 \\
& & & Days & & &
\end{tabular}

D + Tocilizumab + Sarilumab + Control

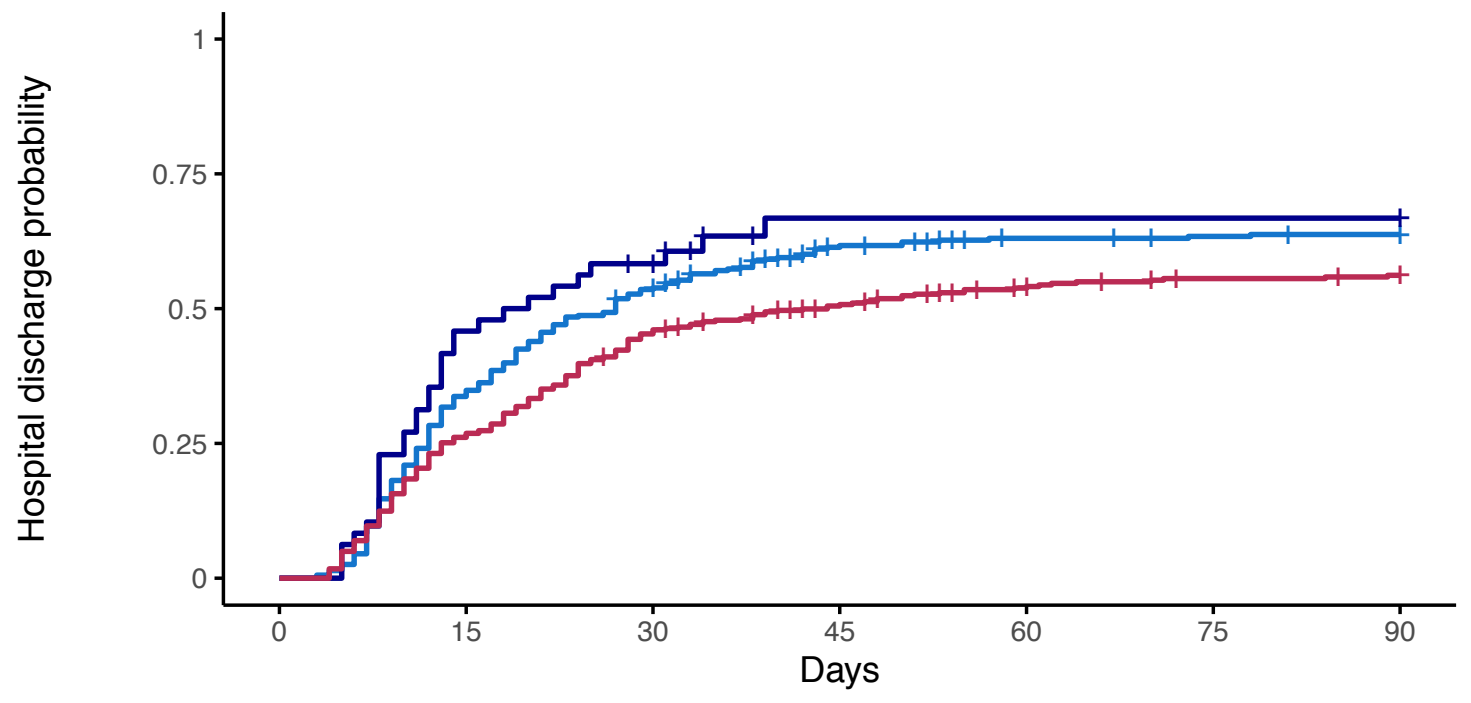

Number at risk

\begin{tabular}{r|ccccccc} 
Tocilizumab & 353 & 234 & 163 & 118 & 106 & 103 & 101 \\
Sarilumab & 48 & 26 & 19 & 10 & 10 & 10 & 10 \\
Control & 402 & 297 & 218 & 182 & 159 & 148 & 145 \\
\hline & 0 & 15 & 30 & 45 & 60 & 75 & 90 \\
& & & & Days & & &
\end{tabular}


medRxiv preprint doi: https://doi.org/10.1101/2021.01.07.21249390; this version posted January 9, 2021. The copyright holder for this preprint (which was not certified by peer review) is the author/funder, who has granted medRxiv a license to display the preprint in It is made available under a CC-BY-NC-ND 4.0 International license .

\section{References:}

1. COVID19 - Numbers at a glance. World Health Organisation, 2020. (Accessed 10

December 2020, at https://www.who.int/emergencies/diseases/novel-coronavirus-2019.)

2. WHO Rapid Evidence Appraisal for COVID-19 Therapies (REACT) Working Group et al.

Association Between Administration of Systemic Corticosteroids and Mortality Among

Critically III Patients With COVID-19: A Meta-analysis. JAMA 2020;324:1330-41.

3. $\mathrm{Xu} \mathrm{X,} \mathrm{Han} \mathrm{M,} \mathrm{Li} \mathrm{T,} \mathrm{et} \mathrm{al.} \mathrm{Effective} \mathrm{treatment} \mathrm{of} \mathrm{severe} \mathrm{COVID-19} \mathrm{patients} \mathrm{with}$ tocilizumab. Proc Natl Acad Sci U S A 2020;117:10970-5.

4. Somers EC, Eschenauer GA, Troost JP, et al. Tocilizumab for treatment of mechanically ventilated patients with COVID-19. medRxiv 2020.

5. Gremese E, Cingolani A, Bosello SL, et al. Sarilumab use in severe SARS-CoV-2 pneumonia. EClinicalMedicine 2020;27:100553.

6. Stone JH, Frigault MJ, Serling-Boyd NJ, et al. Efficacy of Tocilizumab in Patients Hospitalized with Covid-19. N Engl J Med 2020.

7. Hermine O, Mariette X, Tharaux PL, et al. Effect of Tocilizumab vs Usual Care in Adults Hospitalized With COVID-19 and Moderate or Severe Pneumonia: A Randomized Clinical Trial. JAMA Intern Med 2020.

8. Salvarani C, Dolci G, Massari M, et al. Effect of Tocilizumab vs Standard Care on Clinical Worsening in Patients Hospitalized With COVID-19 Pneumonia: A Randomized Clinical Trial. JAMA Intern Med 2020.

9. Salama C, Han J, Yau L, et al. Tocilizumab in Patients Hospitalized with Covid-19 Pneumonia. N Engl J Med 2020.

10. Rosas I, Bräu N, Waters M, et al. Tocilizumab in Hospitalized Patients With COVID-19 Pneumonia. medRxiv 2020:2020.08.27.20183442.

11. Angus DC, Berry S, Lewis RJ, et al. The REMAP-CAP (Randomized Embedded Multifactorial Adaptive Platform for Community-acquired Pneumonia) Study. Rationale and Design. Ann Am Thorac Soc 2020;17:879-91.

12. Angus DC, Derde L, Al-Beidh F, et al. Effect of Hydrocortisone on Mortality and Organ Support in Patients With Severe COVID-19: The REMAP-CAP COVID-19 Corticosteroid Domain Randomized Clinical Trial. JAMA 2020;324:1317-29. 
medRxiv preprint doi: https://doi.org/10.1101/2021.01.07.21249390; this version posted January 9, 2021. The copyright holder for this preprint (which was not certified by peer review) is the author/funder, who has granted medRxiv a license to display the preprint in It is made available under a CC-BY-NC-ND 4.0 International license .

13. Laterre PF, Berry SM, Blemings A, et al. Effect of Selepressin vs Placebo on Ventilator- and Vasopressor-Free Days in Patients With Septic Shock: The SEPSIS-ACT Randomized Clinical Trial. JAMA 2019.

14. Viele K, Berry S, Neuenschwander B, et al. Use of historical control data for assessing treatment effects in clinical trials. Pharm Stat 2014;13:41-54.

15. The Recovery Collaborative Group. Dexamethasone in Hospitalized Patients with Covid-19 - Preliminary Report. N Engl J Med 2020.

16. WHO Working Group on the Clinical Characterisation and Management of COVID-19 infection. A minimal common outcome measure set for COVID-19 clinical research. Lancet Infect Dis 2020;20:e192-e7.

17. Gong J, Dong H, Xia Q, et al. Correlation Analysis Between Disease Severity and Inflammation-related Parameters in Patients with COVID-19 Pneumonia. medRxiv 2020:2020.02.25.20025643.

18. Zhou F, Yu T, Du R, et al. Clinical course and risk factors for mortality of adult inpatients with COVID-19 in Wuhan, China: a retrospective cohort study. Lancet 2020;395:1054-62.

19. Zhou Y, Fu B, Zheng X, et al. Pathogenic T-cells and inflammatory monocytes incite inflammatory storms in severe COVID-19 patients. National Science Review 2020;7:9981002.

20. Pairo-Castineira E, Clohisey S, Klaric L, et al. Genetic mechanisms of critical illness in Covid-19. Nature 2020.

21. Sanofi provides update on Kevzara ${ }^{\circledR}$ (sarilumab) Phase 3 trial in severe and critically ill COVID-19 patients outside the U.S. 2020. (Accessed 22-12-2020, at https://www.sanofi.com/en/media-room/press-releases/2020/2020-09-01-07-00-00.)

22. Fajgenbaum DC, June CH. Cytokine Storm. N Engl J Med 2020;383:2255-73.

23. Sinha $\mathrm{P}$, Calfee CS, Cherian $\mathrm{S}$, et al. Prevalence of phenotypes of acute respiratory distress syndrome in critically ill patients with COVID-19: a prospective observational study. Lancet Respir Med 2020;8:1209-18.

24. Xu C, Rafique A, Potocky T, et al. Differential Binding of Sarilumab and Tocilizumab to IL-6Ralpha and Effects of Receptor Occupancy on Clinical Parameters. J Clin Pharmacol 2020. 
medRxiv preprint doi: https://doi.org/10.1101/2021.01.07.21249390; this version posted January 9, 2021. The copyright holder for this preprint (which was not certified by peer review) is the author/funder, who has granted medRxiv a license to display the preprint in It is made available under a CC-BY-NC-ND 4.0 International license .

25. Colaneri M, Bogliolo L, Valsecchi P, et al. Tocilizumab for Treatment of Severe COVID19 Patients: Preliminary Results from SMAtteo COvid19 REgistry (SMACORE).

Microorganisms 2020;8. 